Nevada

Environmental

Restoration

Project
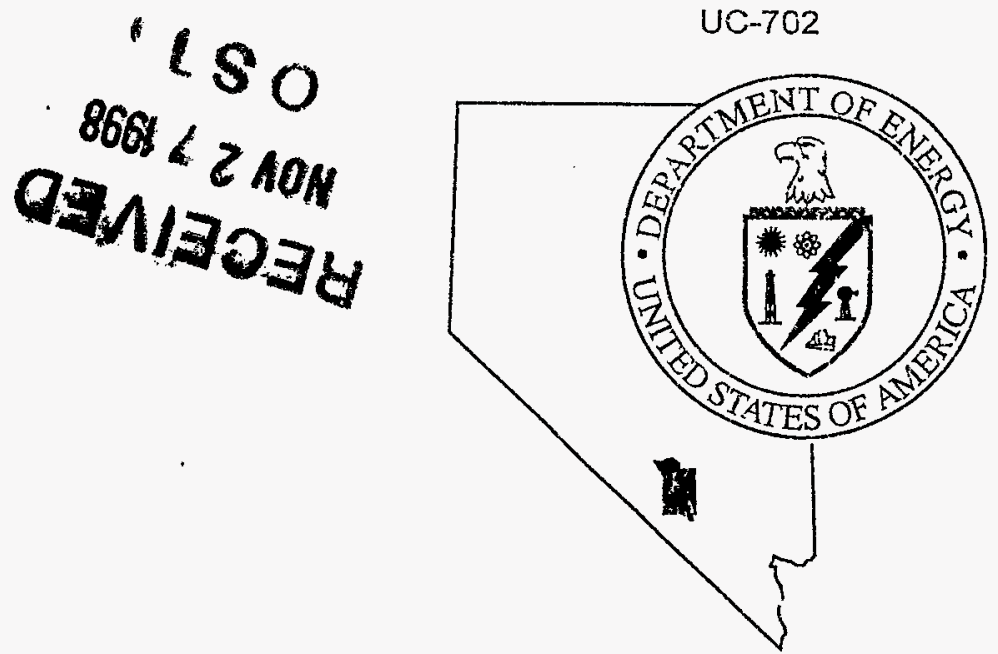

\title{
CLOSURE REPORT FOR DECONTAMINATION \& DECOMMISSIONING (D\&D) CATEGORY, CORRECTIVE ACTION UNIT 95, EPA FARM LABORATORY BUILDING 15-06, NEVADA TEST SITE
}

Revision: 0

February 1998

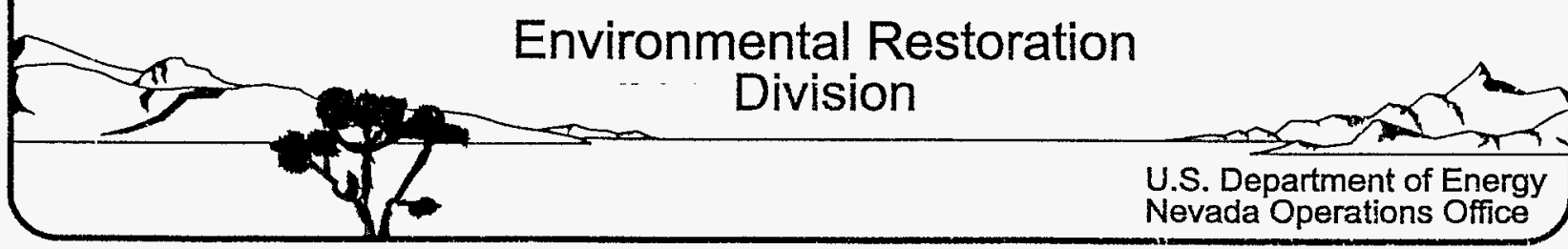




\section{DISCLAMMER}

This report was prepared as an account of work sponsored by an agency of the United States Government Neither the United States Governmeat aor any ageacy thereof, nor any of their employees, makes any werranty, express or impilied, of assumes any legal liability or responsibility for the accuracy, completeness, or usefulness of any information, apparatus, produer, or process diselosed, or represents that its use would not infringe privately owned rights. Refereace berein to any specific commercial product. process, or service by trade anme, trademert, manufacturer, or otherwise does not necessarily constitute or imply its endorsement, recommendation, or favoring by the United States Governmear or any agtacy thereof. The views and opinions of authors expressed herein do not secessarily state or reflect those of the. United States Governmeat or any agency thereof. 


\section{DISCLAIMER}

Portions of this document may be illegible in electronic image products. Images are produced from the best available original document. 


\title{
CLOSURE REPORT FOR DECONTAMINATION \& DECOMMISSIONING (D\&D) CATEGORY, CORRECTIVE ACTION UNIT 95, EPA FARM LABORATORY BUILDING 15-06, NEVADA TEST SITE
}

\author{
Prepared for \\ U. S. Department of Energy \\ Nevada Operations Office \\ Under Contract No. DE-AC08-96NV11718
}

Revision: 0

Prepared by

Bechtel Nevada

Environmental Restoration

February 1998 


\section{CLOSURE REPORT FOR DECONTAMINATION \& DECOMMISSIONING (D\&D) CATEGORY, CORRECTIVE ACTION UNIT 95, EPA FARM LABORATORY BUILDING 15-06, NEVADA TEST SITE}

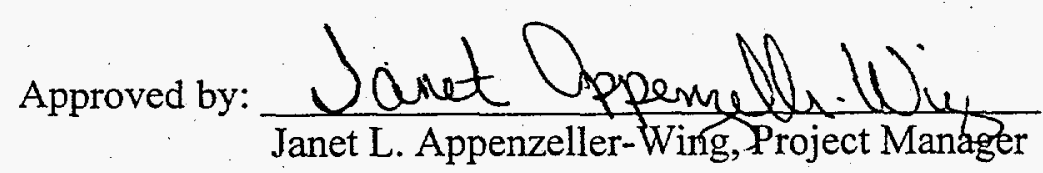
Industrial Sites Subproject

Approved by:

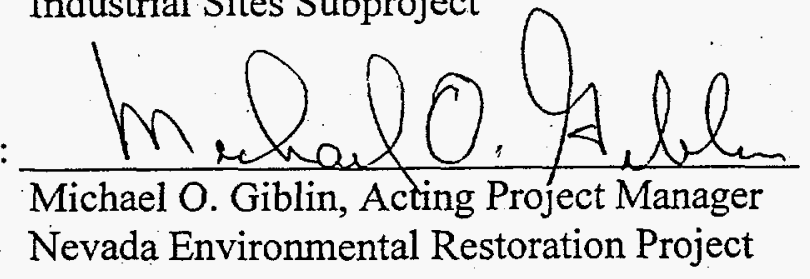

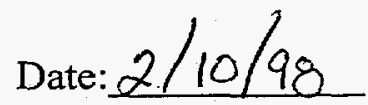

Date: $2 / 10 / 98$ 


\section{FFACO Corrective Action Site \\ Housekeeping Closure Verification Form \\ Closure Report for Decontamination and Decommissioning (D\&D) Category \\ Corrective Action Unit 95, Nevada Test Site}

Closure Verification Date: 24-OCT-97

CAS Number: 15-41-01

General Location: Area 15 EPA Farm

Latitude:

Longitude:
CAU Number: 95

Elevation: 4586 feet

Northing: 895,709

Easting: 682,084

Coordinate/Elevation data from Nevada Test Site Drilling \& Mining Summary, (prepared by Raytheon Services Nevada, 1991) based on water well UE15d.

Site Access Route: From Mercury take Mercury Highway north to Rainier Mesa Road, proceeding northwest, turn north onto 2-05 Road. Continue on 2-05 Road for 4.5 miles and go north at "y" onto Circle Road and continue for 5 miles. Turn north onto 10-02 Road and continue for 1.5 miles. Turn east and go to end of paved road. The U.S. Environmental Protection Agency (EPA) Farm complex is on the right (south).

\begin{tabular}{|l|l|}
\hline \multicolumn{1}{|c|}{ Waste Item(s) Originally at Site } & \multicolumn{1}{c|}{ Apparent Waste Type* $^{-1}$} \\
\hline 1. Piping insulation. & 1. Asbestos-containing material. \\
2. Light ballasts. & 2. Polychlorinated biphenyl-containing material. \\
3. Fluorescent light tubes. & 3. Mercury vapor. \\
4. Refrigerating units. & 4. Ozone-depleting substances. \\
5. Demolition debris (metal, wood, concrete, & 5. Ordinary sanitary waste, scrap metal and other \\
insulation, etc.) & salvageable miscellaneous items. \\
6. High-efficiency particulate air filter banks, & 6. Low-level radioactive waste. \\
plywood, personnel protective clothing, metal, & \\
concrete chips, insulation, etc. & \\
\hline
\end{tabular}

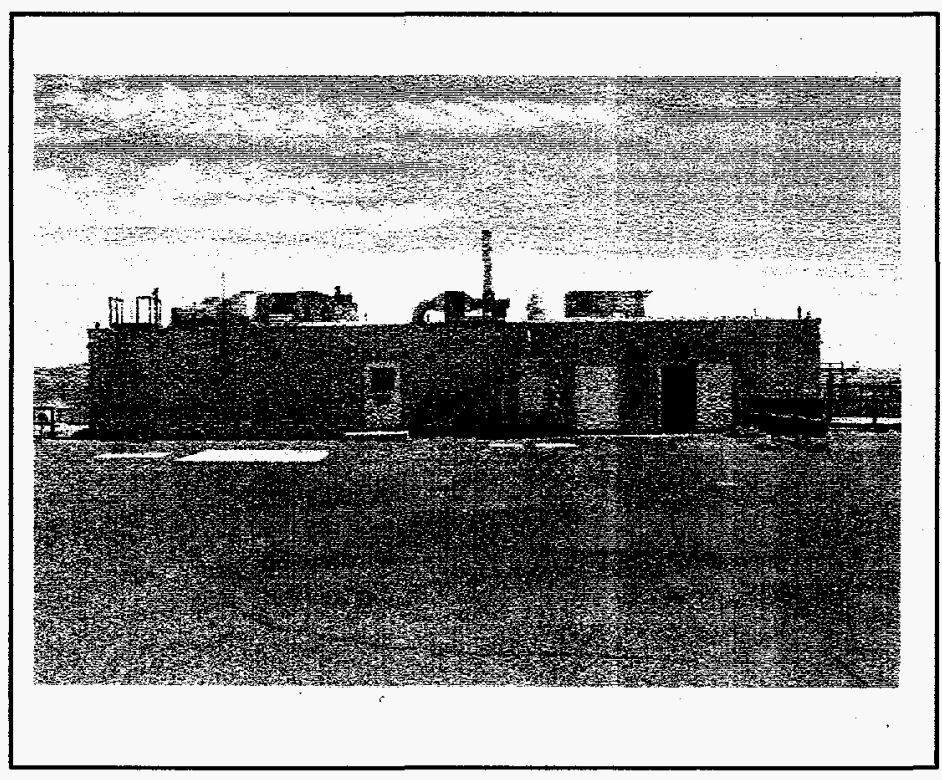

CAS Status Prior To Cleanup

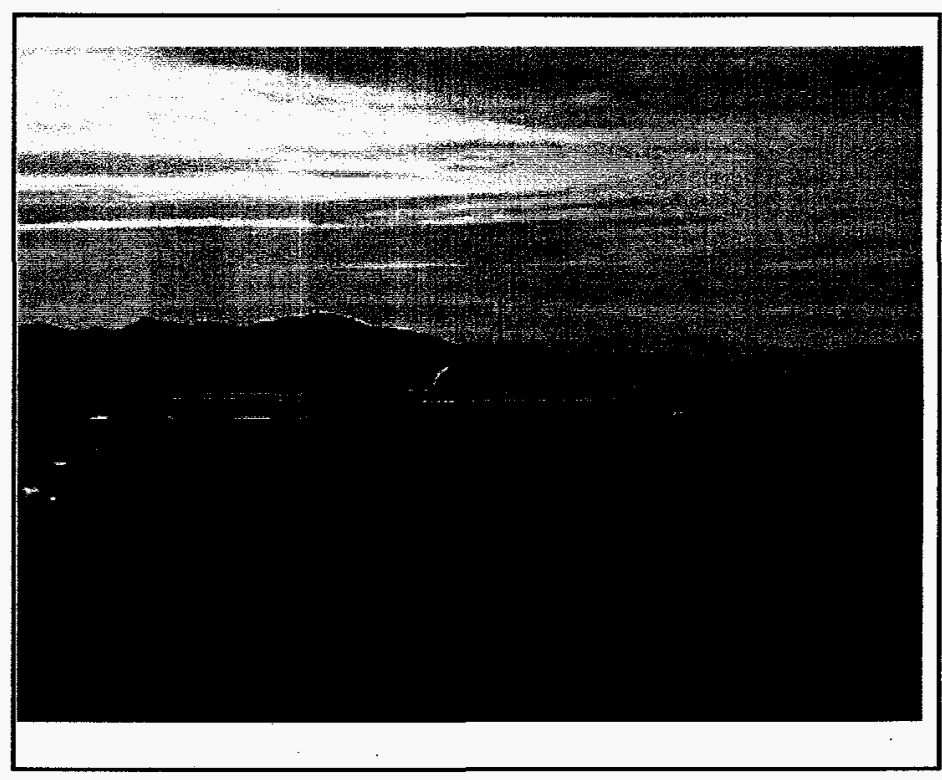

CAS Status After Cleanup 


\section{Current Site Description/Observations:}

The EPA Farm Laboratory Building 15-06 was located in Area 15 of the Nevada Test Site (NTS), Nye County, Nevada. The facility is identified as Corrective Action Unit (CAU) 95, Corrective Action Site 15-41-01, in the Federal Facilities Agreement and Consent Order and was assigned to Functional Category 41 (Decontamination and Decommissioning [D\&D] Facility.) In August 1997, the Department of Energy/Nevada (DOE/NV) accelerated the corrective actions for CAU 95. A final Corrective Action Decision Document and a draft Corrective Action Plan were submitted to the Nevada Division of Environmental Protection (NDEP) and notification was made to the NDEP that work would proceed at the site while the documents were reviewed.

The NDEP approved the decontamination and demolition of the Laboratory Building as the corrective action alternative most suitable for the closure of CAU 95. Closure activities were initiated on September 2, 1997 and completed October 23, 1997. The decontamination of Building 15-06 was accomplished in conformance with the D\&D Subproject Characterization Work Plan and the Quality Assurance Project Plan. The NDEP and DOE/NV agreed that the demolition and disposal of the decontaminated structure was accomplished in a manner consistent with the approved Housekeeping Category Corrective Action Unit Work Plan and that this Closure Report follow the format used for housekeeping sites.

Prior to demolishing the building, all regulated substances were removed and transported offsite. Approximately three 55-gallon drums were filled with asbestos-containing piping insulation which were transported to the Area 9 10c Sanitary Landfill for disposal. The light ballasts were also disposed of in the 10c Landfill. All fluorescent light tubes were collected, transported to Area 6, and placed in a designated storage area until a method of disposal is approved. The low-level radioactive waste was placed in three cargo containers, transported to the Area 6 Waste Handling Facility, where it was repacked for volume reduction, prior to onsite disposal. Eleven loads of salvageable items were transported to the Area 23 Salvage Yard for reuse or sale. A total of 36 loads of demolition debris were transported to the 10c Landfill and disposed of as sanitary waste.

\section{$\checkmark \quad$ No Further Action Required at Corrective Action Site}

Angela L. Olson Corrective Action Coordinator/Designee

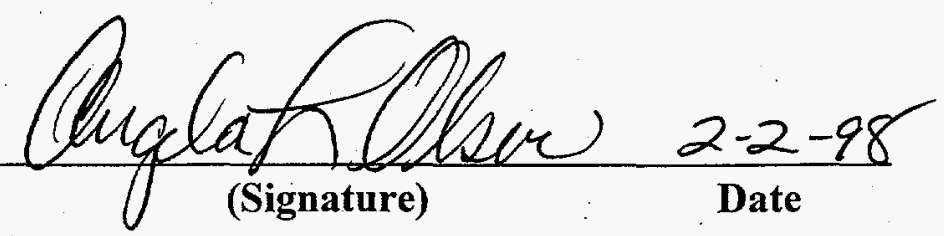




\section{DISTRIBUTION LIST}

Copies

U. S. Department of Energy, Nevada Operations Office

P. O. Box 98518

Las Vegas, NV 89193-8518

J. L. Appenzeller-Wing

C. W. Barrow

S. D. Bonnell

Public Reading Room

Technical Information Resource Center

U. S. Department of Energy,

Office of Scientific and Technical Information

175 Oak Ridge Turnpike

P. O. Box 62

Oak Ridge, TN 37831

Bechtel Nevada

P. O. Box 98521

Las Vegas, NV 89193-8521

D. K. Cowser

R. H. Guymon

S. J. Nacht

A. L. Olson

M. A. Sabbe

M. D. Shotton

PEER Consultants

P. O. Box 98521

Las Vegas, NV 89193-8521

G. G. Hudak 